\title{
Toward a Critical Turn in Library UX
}

\section{Maura Seale, Alison Hicks, and Karen P. Nicholson}

In the past decade, cataloguing and classification and information literacy have experienced a critical turn, acknowledging the political, economic, and social forces that shape complex information environments. Library user experience (UX) has yet to undergo such a transformation, however; instead, it continues to be seen as a toolkit of value-neutral approaches for evaluating and improving library services and spaces to enhance user satisfaction and engagement. Library UX draws upon ethnography but is also informed by the principles and values of usability and design. Little attention has been paid to the origins or epistemological underpinnings of UX as a construct, the ways these inform UX practice, and, ultimately, how they impact what academic libraries are and what they do. With the exception of a 2016 article by Lanclos and Asher, the relationship among corporatism, UX, and the mission and values of academic libraries has yet to be acknowledged or examined. This paper seeks to address this gap by drawing upon literature from LIS, anthropology and human computer interaction to interrogate library UX. While a handful of library UX practitioners have started to promote a more thoughtful study of individuals' activities and needs, in the main, library UX remains a theoretically weak practice, one that sets out to solve complex problems with practical "solutions." The failure to interrogate UX as a construct and a practice necessarily forecloses the user-centered problems we address, the tools and strategies we use, and the solutions we propose. We contend that UX would benefit from a deeper engagement with user-centered theories emerging from Library and Information Science (LIS) and critical and feminist perspectives on practice, embodiment, and power or risk perpetuating oppressive, hegemonic ideas about the academic library as a white space and its users as able-bodied.

\section{Introduction}

In the past decade, cataloguing and classification and information literacy have experienced a critical turn, acknowledging the political, economic, and social forces that shape complex information environments. Library user experience (UX) has yet to undergo such a transfor-

\footnotetext{
*Maura Seale is History Librarian at University of Michigan; email: mseale@umich.edu. Alison Hicks is Assistant Professor, Department of Information Studies at University College, London; email: a.hicks@ucl.ac.uk. Karen P. Nicholson is Manager, Information Literacy at the University of Guelph and an adjunct instructor in the Faculty of Information E Media Studies, Western University; email: kanichol@uoguelph.ca. We would like to thank Robin Bergart, Assessment $\mathcal{E}$ User Experience Librarian, University of Guelph for her comments on an earlier draft of this work and the CLAPS conference as a venue to explore critical approaches to librarianship and pedagogy. (C2022 Maura Seale, Alison Hicks, and Karen P. Nicholson, Attribution-NonCommercial (https://creativecommons.org/ licenses/by-nc/4.0/) CC BY-NC.
} 
mation, however; instead, it continues to be seen as a toolkit of value-neutral approaches for evaluating and improving library services and spaces. As a profession, we appear reluctant to probe or question the origins or epistemological underpinnings of UX as a construct, the ways that these inform UX research and practice and, ultimately, their impact on the mission and values of academic libraries. In the main, library UX remains distanced from critical considerations, including broader questions of power and representation. This lack of critical engagement means we risk designing user systems, spaces, and services that perpetuate oppressive, hegemonic ideas about the library as a white space and its users as able-bodied. ${ }^{1}$ These shortcomings, coupled with our belief that critical insight enhances our ability to build meaningful library systems, provides an important rationale for the following interrogation of library UX work.

Drawing upon the work of those few library UX practitioners who have begun to question the assumptions and values of library $\mathrm{UX}^{2}{ }^{2}$ as well as literature from anthropology, human-computer interaction (HCI), and Library and Information Science (LIS), in this article, we uncover and interrogate the origins and values of UX with the goal of drawing out the implications for library workers and their communities. We begin by considering the ways in which the concept of UX, with origins in HCI, industrial design, and applied anthropology, has been adapted within library discourse and practice and then focus our attention on UX's two foundational concepts, user and experience. Concluding that both concepts reproduce the library as a space where "belonging is constructed around whiteness" 3 and being able-bodied, we advocate for a critical turn in library UX, one that would result from a deeper engagement with user-centered theories that emerge from LIS as well as critical and feminist perspectives on practice, embodiment, and power.

\section{What Is UX?}

UX forms an elusive concept; while it has been widely accepted by a range of researcher and practitioner communities, its various origins and influences mean that it resists a neat or cohesive definition. ${ }^{4}$ This "denotational indeterminacy," which allows discourses to be strategically deployed in a variety of contexts to serve a variety of needs, ${ }^{5}$ is no doubt part of UX's broad appeal. Complicated through its derivation from both science and social science disciplines, including cognitive science, engineering, HCI, anthropology, psychology, and sociology, UX has further been confused by its close relationship with the concept of usability. These issues have led to the emergence of numerous, occasionally conflicting ideas about UX.

One of the most prominent definitions of UX is put forth by the Nielsen Norman Group. Establishing that "exemplary user experience" occurs through the fulfillment of a customer's "exact needs" and through "products that are a joy to own, a joy to use," 6 the Nielsen Norman Group definition equates UX with satisfaction, the degree to which a user's expectations of a product, service, or system are met. UX is thereby distinguished from usability through a focus on holistic interactions rather than interactions uniquely mediated by interfaces. User gratification also features in research put forth by the Association for Computing Machinery (ACM) that differentiates UX from usability through an emphasis on "user affect and sensation"; UX is seen to have emerged from a growing awareness "of the limitations of the traditional usability framework, which focuses primarily on user cognition and user performance in human-technology interactions." 7 These ideas position UX as an individual phenomenon rather than a shared experience as "only an individual can have feelings and experiences." 8 
In contrast, the International Organization for Standardization (ISO) brings a more pragmatic focus to understandings of UX by emphasizing the "brand image, presentation, functionality, system performance, interactive behaviour, and assistive capabilities of a system, product or service" as well as the user's "internal and physical state." Merging principles of marketing and industrial practice with nonutilitarian aspects of a user's experience, these definitions provide a first indication of some of the tensions and contradictions that structure the UX narrative.

The history of UX reinforces many of the inconsistencies highlighted in the definitions above. According to corporate ethnographer and scholar Shaheen Amirebrahimi, UX was first developed as applied anthropology in the 1980s when the increasing integration of technologies into everyday work and life events captured the attention of researchers at Xerox PARC, who began to study user interactions with machines. ${ }^{10}$ Engineer and cognitive scientist Donald Norman, who later co-founded the Nielsen Norman Group and authored the well-known book, The Design of Everyday Things, played an important role in bringing both usability and user-centered design to bear on product development through his work at Apple during this time. ${ }^{11}$ Eventually, efforts by these and other tech companies, and influences from adjacent fields, including participatory design, led to the establishment of ethnography and ethnographic methods as integral to corporate innovation and product design. Mirroring cycles of economic growth and recession, the popularity of UX waxed and waned in the 1990s. In the decade that followed, however, UX became formalized as a "kind of everyday anthropology" used to empower consumers "with choices via products designed for people."12 Nonetheless, it was not until 2007 that UX entered the mainstream: during the launch of the iPhone, Apple CEO Steve Jobs identified the "user" and their "experience" "as the pivotal focus for the next era of technology production." ${ }^{13}$ With this statement, Jobs introduced the idea of selling "experiences" rather than just products into the UX narrative, reinscribing consumerism as performative identity. From this moment, UX became perceived by Silicon Valley as a "breakthrough innovation,"14 effectively sweeping up and absorbing ethnography into the cornerstones of product design and development. As ethnographic methods became central to product development, the history and theory embedded within them became erased. ${ }^{15}$

This narrative is complicated, however, by accounts that link the emergence of UX to the development of the commercial web between 1990 and 2005 and, more particularly, to the dot-com crash of 2001. From this understanding, the collapse of internet startups in the early 2000s and the shift from "read-only" to "read-write" websites, seen to herald a new participatory internet era, generated "a newfound interest in the user." ${ }^{16}$ Correspondingly, the association of existing design principles with past excess gave way to "a new discourse of usability, which featured the user instead of the designer." ${ }^{17}$ The recognition that the incorporation of participatory design principles into website design would offer newly out-ofwork tech consultants an opportunity to resurrect their careers and the internet's commercial potential did not go unnoticed..$^{18}$ Between 2001 and 2005, web design consequently became framed in terms of the user and their experience or UX, which was understood to encompass the feel or aesthetics of an interactive environment as well as its function and efficiency. ${ }^{19} \mathrm{UX}$ became codified through the development of practices based on many of the hallmarks of Web 2.0, including the promotion of "ordinary users over star designers, participation over publishing, and sharing over surfing." ${ }^{20}$ An emphasis on creating and maintaining enduring relationships between customer and brand, bringing a new focus on return on investment (ROI) and business value to the UX narrative, established UX as integral to "product man- 
agement and customer service." 21 These various influences highlight the important role that social and economic pressures have played, and continue to play, in shaping understanding of user-centered design. ${ }^{22}$

Beyond web design, UX has also been linked to early user-centered research from LIS. LIS has an established history of user studies; Bawden dates the earliest research to $1948 .{ }^{23}$ Herner locates it even earlier, in 1927, although he also decries such work as "academic exercises" and suggests that most LIS information systems are "based on only vague notions of the real needs, habits, and preferences of their presumed users." ${ }^{24}$ In contrast, by 1976, Martin confidently claims "studies of use and users are becoming fairly standard in library planning, and attest to a changing concept of what constitutes effective service," suggesting a growing interest in incorporating a user focus into everyday library practice. ${ }^{25}$ The influence of LIS is also noted outside the field; writing from a communication studies perspective, Ankerson states that UX integrates "insights of user-centered design methodologies from library and information sciences." ${ }^{26}$ Likewise, in a 2017 book on the evolution of human-computer interaction, Grudin underscores the connections between HCI, LIS, information systems, ergonomics, and human factors engineering, all of which share an interest in the relationship between users and information systems, and their respective influences on the development of UX. ${ }^{27}$ However, while LIS research is identified within early UX narratives, its influence, rarely acknowledged within contemporary library UX studies, appears to be subsequently forgotten, once again highlighting the erasure of disciplinary epistemology as an outcome of the institutionalization of UX.

In summary, these parallel narratives suggest that, while UX emerged from usability (HCI) in the 1970s and was shaped through the influence of applied ethnography in the 1980s, it became established as a routine process in industrial innovation in the 1990s. The development of the commercial web and the dot-com crash subsequently paved the way for its institutionalization within Silicon Valley firms; today, UX is engrained within a broad range of domains, including higher education. In addition to demonstrating that claiming authority over a domain of professional knowledge and practice is central to the emergence and proliferation of UX, these somewhat contradictory accounts of early influences within UX also belie a focus on commercial success beyond broader questions related to form and function.

\section{What Is Library UX?}

Many, if not all, of these entangled threads are seen within current conceptions of library UX, which aims to understand and improve the ways in which communities engage with libraries and library workers and encompasses a wide range of activities, "including but not limited to assessment, user engagement, library design, outreach, and marketing." ${ }^{28}$ As a result, library UX can be seen as similarly shaped by competing values and ideas rather than forming a simple and unambiguous concept.

The origins of library UX are murky, like those of UX more broadly, but they are most frequently traced to Foster and Gibbons's groundbreaking ethnographic work at the University of Rochester in the United States. ${ }^{29}$ In this study of undergraduate research habits, Foster and Gibbons drew from applied anthropological traditions to examine how "papers happen" and the various ways in which libraries could support research-related needs. ${ }^{30}$ Focusing attention on campus buildings as well as services and digital presences, this work stood out from the library community needs analyses that had been carried out since the nineteenth century ${ }^{31}$ for 
emphasizing the full context of student academic work rather than just the library's role within it. ${ }^{32}$ Foster and Gibbons's use of participatory and qualitative research methods introduced a new engagement with design into user-centered research and extended the scope of library assessment practices beyond the prevailing reliance on quantitative satisfaction measures, such as LibQUAL. Emerging at a time when libraries were grappling with the installation of learning commons ${ }^{33}$ as well as increasingly "self-service" campus cultures, ${ }^{34}$ Foster and Gibbons's work introduced a promising and invigorating focus on student learning within academic libraries that aligned with broader campus priorities. It consequently inspired several related projects, including the multisite, multiyear ERIAL project as well as more widespread interest in studying information-related human activity. ${ }^{35}$

By 2012, however, time and budget constraints meant that "results-oriented libraries and library directors" were starting to look for simpler ways to understand and build responsive library spaces. ${ }^{36}$ While interest in ethnography remained high, the "messiness" of qualitative data ${ }^{37}$ meant that long-term, exploratory fieldwork approaches were beginning to lose their shine. At the same time, interest in integrating web 2.0 features and design principles ${ }^{38}$ into library websites was also on the rise. The concept of user experience, which weaves together "ethnography, usability, and space and service design techniques under one umbrella," 39 offered a pragmatic, flexible solution, and the first library UX studies emerged soon after. Centering the creation of "useful, usable and desirable" information systems, ${ }^{40}$ library UX introduced a more explicit focus on digital spaces and strategic design processes to usercentered studies. ${ }^{41}$ In further drawing attention to the creation of "holistic and positive" library touchpoints, ${ }^{42}$ library UX also elevated the concept of user satisfaction and the fulfillment of task-oriented goals. ${ }^{43}$ The positioning of library UX as offering a useful "low-investment, highyield" ${ }^{44}$ means of revitalizing engagement with and use of libraries illustrates how these new areas of interest emerged from and tapped into ongoing fears of library irrelevancy within "rapidly changing," 45 "sensorily overloaded," ${ }^{46}$ and millennial ${ }^{47}$ information environments.

The explicit inclusion of library websites and digital interfaces within these new forms of user research means that library UX owes a considerable debt to the concept of usability. Usability has a long history within libraries. Initially positioned as helping to free librarian time, ${ }^{48}$ usability was later understood to benefit the library patron by increasing their productivity, allowing them to keep up in a fast-paced world..$^{49}$ Sharing the same user-centered focus and participatory research approach that characterizes ethnography, albeit in digital rather than physical environments, usability has been similarly characterized as helping libraries to remain relevant at a time when commercial websites were seen to disadvantage them. ${ }^{50}$ However, with origins in the fields of market research, ergonomics, and engineering, ${ }^{51}$ usability also subtly diverges from early ethnographic studies by introducing an emphasis on testing, rather than observation, to user-centered library research. More specifically, the use of quantitative assessment methods in usability studies, including error rates and completion time, brings a renewed interest in benchmarking and performance metrics to the enhancement of library websites, services, and spaces..$^{52}$ The frequent equivalence of user-centered design with ease of use means that usability studies, which draw attention to an individual's emotional responses to a product or platform rather than to a group's shared patterns of activity, can also be seen to be responsible for the emphasis on effect within library UX..$^{53}$

The important role that innovation plays within library UX stems from design thinking, a third influence within changing user research methods. Originally championed by 
the design consultancy IDEO, design thinking was first explored in the context of academic libraries through Bell and Shank's 2007 book, Academic Librarianship by Design: A Blended Librarian's Guide to the Tools and Techniques. ${ }^{54}$ Design thinking introduced a lean, iterative, and collaborative approach to library UX and the development of services, spaces, and tools. ${ }^{55} \mathrm{An}$ emphasis on desirability ${ }^{56}$ (alongside technological feasibility and financial viability) embedded concrete and recognizable customer service ideals within user-centered library research, as illustrated by the push to create memorable Facebook-type "moments" and Amazon-like "experiences." ${ }^{57}$ The emphasis on the creative generation of solutions to identified problems meant that design thinking also brought a more process-driven and pragmatic approach to the study of user activity. These ideas drew attention to an individual's immediate needs rather than broader future-oriented goals or environmental and social concerns within library user studies. ${ }^{58}$ Nonetheless, design thinking's supportive structure and fast, proactive, problemsolving approach meant that it appealed to librarians pressured to respond to evolving research demands and changing campus demographics. ${ }^{59}$ The push for evidence-based solutions also mirrored a growing desire for more "rigorous" approaches to the design of library services and spaces, an idea that recalls Ankerson's observation of a push for rationality within usability testing in commercial web design. ${ }^{60}$

By 2014, library UX, which had rarely been seen within user-centered library literature before 2012, ${ }^{61}$ had become established as "the next big thing" 62 within Anglo-American academic librarianship. These developments had important implications: the more applied, solution-oriented approach to research, which differs from ethnography's focus on the production of social understanding over time, meant that library UX began to be employed within an increasing number of short-term projects, including the design of electronic resources management, new employee onboarding, and collection development, ${ }^{63}$ as well as the more typical engagement with library spaces and web resources. Growing interest also led to the establishment of Weave: Journal of Library User Experience in 2014 and the UXLibs conference in 2015, and the continued creation of UX-focused library positions. Most recently, library UX has started to develop in new directions, including becoming more closely associated with quality assurance processes and the measurement of library value. ${ }^{64}$ This trend reflects a growing interest in "student experience," part of the push toward more accountable systems of higher education. It remains to be seen whether user-centered library research will return, full circle, to a predominantly quantitative and assessment-focused model of practice; in the meantime, however, the complexity of multivendor information environments and changing user demographics means that UX continues to play a central role in libraries.

Somewhat surprisingly, critical engagement with the precepts and practices of UX has emerged only recently in the LIS literature. Lanclos and Asher's characterization of library UX as "ethnographish" rather than as focused "on the larger perspective on insight and meaning that is inherent in particular to anthropological approaches to ethnography," published in 2016, remains one of the most cogent criticisms to date. ${ }^{65}$ More recently, greater attention has been paid to the assumptions that lie behind many UX projects; as Andrews points out, a failure to interrogate UX methods runs the risk of designing services for majority groups and treating "other groups such as disabled users, part-time students, older users, non-native English speakers and so on as add-ons." 66 Young and Brownotter and Cooper have taken a similarly deliberate approach in their respective work with indigenous students and scholars, noting that building libraries that both listen and respond to indigenous researchers requires 
the modification of UX and participatory design processes. ${ }^{67}$ For the most part, however, library UX remains distanced from critical considerations, including broader questions about issues of power and representation. The recognition that library user-centered research draws, somewhat indiscriminately, from the various entangled threads that constitute the broader UX narrative provides a further illustration of the need to critically interrogate the values and assumptions that lie behind this work.

\section{Interrogating User Experience}

In the next section, we turn our examination of UX's two foundational concepts, user and experience, to argue that both concepts elide a number of problematic issues, including considerations of labor and value as well as the reproduction of the academic library as a heterotopia ${ }^{68}$ or "fantasy space" 69 designed for majority user groups.

\section{The User}

The concept of the user is central to definitions and understandings of UX to date. Differentiating the second generation of web design from the first, an emphasis on the user and their sensations distinguishes UX from usability. ${ }^{70}$ It also mirrors the user-centered turn, informed by interpretive and qualitative understandings of human activity, that swept across LIS in the 1990s. ${ }^{71}$ However, on closer inspection, UX can also be seen as holding a curious, problematic relationship with the term user. This is to say that, while UX moves away from cognitive models of HCI toward an emphasis on affect, user discourse remains at odds with broader questions of identity and corporeality. These issues will be explored in relation to user terminology itself, the use of persona methods, and broader questions of labor.

A focus on the user, which is perceived to bring a more useful person-centered perspective to information research, emerged from the turn away from the systems-centered cognitive model of human computer interaction. ${ }^{72}$ Moving attention from the categorization of users according to "systems features and variables,"73 the user-centered shift ushered in greater emphasis on the users themselves: their context, their viewpoints, and their needs. Nonetheless, the term has proved to be problematic. Tuominen's analysis of Kuhlthau's informationseeking model, for example, which demonstrates how the user is often portrayed as ignorant or as dependent upon the beneficence of the expert librarian, illustrates the assumptions that are embedded in the term. ${ }^{74}$ Within UX research, where the needs of the organization determine who is a user and whose experiences are valued, therefore, user is similarly coded; the positioning of the UX practitioner as the only person who can reveal and remedy the user's "pain points" not only substantiates the self-legitimizing discourse of UX but also neglects to interrogate the power relations that lie behind this positioning. Moreover, as Cohen points out, when "we identify a thing that we want to study, then look for 'users' of that thing," position people as appendages to a system with little autonomy of their own. In establishing a series of binary relationships-user/used user/nonuser user/designer-UX design flattens the human condition by "occlud[ing] most of the ways in which people interact with things, and with each other." ${ }^{\prime 76}$ It further risks naturalizing consumerism as the dominant relationship between people and their environment. ${ }^{77}$ Similar problems have been noted within library UX, where Reidsma notes that librarians and library vendors frequently test "existing software to see if it is usable... rather than doing ethnographic research to determine the actual needs of a user community." ${ }^{17}$ Demonstrating that the user is still frequently defined 
in technological terms alone or in relation to the system rather than as a cocreator of artifacts and processes, these ideas also hint at the limitations of library UX projects when they rely on narrow interpretations and understandings of the people behind the user label and the ways they can foreclose "the radical unpredictability of the relationship between a product and the people who encounter it."79 Science and technology studies scholars have long argued that affordances are inscribed with and reproductive of social and cultural values; "design (affordances, objects, systems, processes) simultaneously distributes both penalty and privileges" according to identity and positionality.$^{80}$ In this way, the purported rationality of the design process mitigates responsibility for design failure while further subordinating the user to the system. And yet, within the LIS literature at least, design has largely been portrayed as a creative, value-neutral process rather than a political one. ${ }^{81}$

\section{Personas}

The use of personas as a "conceptual stand-in" for groups of potential users ${ }^{82}$ represents a related site of tension within the user framework. First used by Cooper in 1999 and emerging from market segmentation analysis, ${ }^{83}$ personas were developed to replace "the fairly one-dimensional, de-personalised truncated user" with more fulsome characters developed through ethnographic research. ${ }^{84}$

Intended to be memorable-personas are "fleshed out" using "a portrait, background information, and other fictional details ... to help make them feel like a real person" ${ }^{\prime 25}$, these archetypal characters are employed to ensure that user needs and goals are kept at the forefront of the design process. However, in facilitating empathy with and understanding of users among designers, the use of personas arguably serves the designer more than the user. The creation of a "shared vision" and "a common, consistent vocabulary," for example, consolidates users' complex needs to allow the UX team to prioritize and streamline its work. ${ }^{86}$ As boundary objects that facilitate collaboration between teams, personas also form political tools that serve "to reduce conflict or win certain political disputes within the design team" 87 rather than to uniquely or accurately represent user needs and desires. Ultimately, personas reinforce the system-centered focus within the user framework highlighted above by recasting the behaviors, motivations, frustrations, and end goals of target users for a product or service as anthropomorphized lists of product requirements.

Personas are frequently constructed without reference to user research, an issue that has led Saffer to refer to them as a "designer's imaginary friends." 88 These issues are particularly problematic within "ethnographish" library UX projects that are "primarily concerned with short-term data collection," and the use of "'off-the-shelf" methods" that are neither fully engaged with nor trusted. ${ }^{89}$ Even when personas are based on real data, this data is often derived from "learning management or enrollment systems" or surveys such as LibQUAL, "quantifications [that] tell us very little about the lived experience of being a student, or a researcher, or an instructor, who participates in the academic processes of a university." 90 The creation of user profiles based on such quantifications also flattens differences by positioning otherwise diverse groups and communities as simulacra or "deceivingly interchangeable" representations of "people who do not, ultimately, exist." 91 Forming a "cognitive economy"92 or "shorthand" generalizations occlude "the very detail we are trying to capture or include." 94 They may also lead to stereotyping; as Hudson points out, shared conceptual frameworks that rely on 
"existing ways of knowing, on received languages" function as unmarked sites of power. ${ }^{95}$ Within library UX, Andrews and Larose and Barron chronicle the ways that library UX is designed for white, college-age, English-speaking, able-bodied students. ${ }^{96}$ However, there has been little sustained examination of the ways in which a reliance on personas or archetypes reinforces stereotyping, including whiteness, ageism, and ableism, and facilitates oppressive, hegemonic ideas about the library as a white space.

\section{Laboring Bodies}

The complex relationship that UX has with the body is also manifest in the simultaneous exploitation and erasure of physical and emotional labor within library UX. Personas, which constitute disembodied and two-dimensional stand-ins, offer one example of this process; the assessment of library services provides another. Service design, which is a method for evaluating how users interact with library systems and processes, is a form of UX that aims to encourage the provision of holistic, cocreated services. ${ }^{97}$ Positioning everything in the library as a service, service design emerges from the premise that a focus on the user's experience rather than that of the service provider will facilitate more streamlined and efficient modes of engagement. ${ }^{98}$ However, in emphasizing the intangibility of services, which are defined as "unseen exchanges that happen everywhere," physical and emotional labor of service delivery as well as the physical, corporeal aspect of "co-creating" and receiving such labor. ${ }^{100}$ The labeling of the entire library as a service, including collections and physical spaces, exacerbates the issue, flattening and subsuming the pink-collar emotional labor of library workers until it becomes immaterial, made manifest and considered only in the moment of exchange, of consumption. ${ }^{101}$ Perhaps in an attempt to validate the user's experience as different from but equally worthy of the expertise of the service provider, this framework also invalidates expertise; expert knowledge can only be gauged through the user's experience of it. These ideas are further illustrated through the compression of complex processes "into single touchpoints and interactions," which, again, are only seen to have value through the creation of "service moments" for the user. At the same time, and somewhat paradoxically, however, library UX exploits bodies by using them in the library's ongoing enterprise to demonstrate value. To understand the user's experience and to assess service quality, we need to make the immaterial material, to get inside our users' heads. We do this by observing students or getting them to "think aloud," to verbalize, to card sort, to do. The same is true in outcomes-based education, which requires students to demonstrate evidence of "understanding" through the production of artifacts. We also transform the traces of human activity - touchpoints, "pain points," interactions, and maps-into the external expressions of desire, satisfaction, happiness, frustration, or curiosity. In this light, library UX renders the body hyper(in)visible, ${ }^{102}$ dissected publicly while simultaneously being shunned and typecast as the library seeks to demonstrate its ongoing value. Through the use of "neutral," objective artifacts, such as maps, logs, and diaries to represent experience, bodies and labor are erased, underscoring the fact that representation is always partial and political.

A similar erasure of physical and emotional labor is seen in UX understandings of what library interactions should look like: "seamless," "frictionless," and pain-free ${ }^{103}$ experiences that evoke white, heteronormative, able-bodied male subjects engaging effortlessly and productively with library staff, services, spaces, and collections. Such understandings invalidate work that draws attention to the often traumatic experiences of BIPOC and people with dis- 
abilities in academic libraries. ${ }^{104}$ Easing "friction" removes the "messiness" of human interactions. ${ }^{105}$ Personal histories and complex, intersectional identities are flattened and distilled into "personas, user case studies, scenarios, and day-in-the-life timelines."106

\section{Experience}

Experience, the second major concept within UX, refers to an individual's apprehension or impressions while interacting with objects and services. Incorporating physical, mental, and sensory responses, experience is produced through "the various ways in which people create and are formed within their relationships with stuff, with other people, with groups of people and with networks of technologies." 107 The concept of experience is also starting to be employed beyond UX, most prominently within higher education in terms of "the student experience." Emerging from growing focus on "student choice," the student experience has been critiqued for homogenizing, commodifying, and diminishing both students and the concept of experience. ${ }^{108}$ Similar issues can be seen within UX.

Much like user terminology, the concept of experience forms an umbrella term for a number of contentious ideas. John Dewey originally linked experience to education; learning was understood to be shaped by personal experience or interaction as well as the relating of new information to prior knowledge and understanding. ${ }^{109}$ In this view, experience was positioned as both continuous and interactive or as connected to the learner's social context and environment. However, within the context of UX, experience is understood as something individual, emerging uniquely in the moment of a person's interaction with a "product, system, service or object"110; it is disconnected from context, community, and culture. From this perspective, the user's experience is consigned to a vacuum, seen as both isolated and insulated from the broader environment in which it takes place. ${ }^{111}$ These ideas are problematic because they fail to account for the affordances of a setting or the structural and contextual issues that impact a person's opportunities to engage with a library object or service. They also work to homogenize users by downplaying or simplifying differences; experience is always understood in the singular. Experience is further decontextualized and dehumanized through the focus on users, which removes service providers from the interaction. The silencing of alternative understandings of experience, which discounts professional labor, also eliminates the power relations that shape the operationalization of the tool or system in question. A focus on experience, which is typically understood as giving users a voice, consequently constrains human agency by isolating people "from other voices around [them], and from the complex environment that enables us meaningfully to interpret those voices."112

\section{Experience, Innovation, and Time}

The concept of experience is further complicated when it is explored through the lens of time. The basic premise of UX is that users must be put at the heart of the system; the user of the service or tool in question is seen to be best placed to make a judgment about the structure and design of resources. These assertions are, as Sabri points out, often accompanied by a sense of righteousness, as if the inclusion of other perspectives would fail users in some way. ${ }^{113}$ However, when UX is explored through the lens of time, which forms "an invisible and unremarked"114 site of power, it is clear that the concept of experience is shaped by pressures that go far beyond user needs and wants. Early UX, for example, was seen as a way to keep step with the future of the commercial web as well as to provide organizations with 
valuable insights into trends and "insights that can appear predictive of the future."115 Similar influences are noted by Amirebrahimi, who contends that industrial ethnographers function within "a set of institutional relationships which demand a continual and fast paced churning out of 'newness' in data and insights for decision making." 116 In this light, experience cannot uniquely be understood as related to and representative of users' aesthetic engagement with a product or service. Instead, experience becomes entwined with attempts to read the future, to create value, and to make strategic decisions and generate profits; research is a "political necessity" that aims to ensure that corporations feel secure in their existing identity, products, and services, thereby justifying their own stasis. ${ }^{117}$

In many ways, the emphasis on future-facing innovation directs academic libraries and library UX as well. Academic libraries have always been bureaucratic and risk averse. ${ }^{118}$ Today, they have even become "McDonaldized": focused on efficiency, calculability, predictability, and control. ${ }^{119}$ Nonetheless, mainstream professional discourse exhorts academic libraries to demonstrate their capacity for innovation, collaboration, and their support for the university's mission or risk their future survival. ${ }^{120}$ Glassman describes an "innovation fetish" within academic libraries, one situated within "a deeply corporatized" higher education sector that resembles Silicon Valley. ${ }^{121}$ The library UX literature also makes a direct link between the survival of the library and UX:122 "the future state of academic libraries ....is connected to better understanding the user and their needs."123 These ideas demonstrate that the concept of experience is also understood in terms of social control and entrepreneurism. Paradoxically, library UX may also be invoked to create the appearance of change to demonstrate the resilience and continued relevance of the profession. ${ }^{124}$ For example, one disillusioned UX librarian interviewed by MacDonald opines "having a UX librarian on staff makes it at least seem more like the library is hip and moving forward in a faster way than may be true." 125 In some cases, earlier ethnographic research projects within libraries are replicated and repurposed as library UX, which further calls attention to UX as a performative practice. ${ }^{126}$

A temporal lens demonstrates that the employment of typical library UX methods further strips experience of its user focus. One of the main problems identified with library UX - and acknowledged by those who engage in this work themselves - is that it is "crude": drawing heavily upon the principles of design, it uses fast capitalist lean production methods based on rapid prototyping and iterative improvement, as demonstrated by the emphasis on "low barrier," "guerrilla-type" "DIY solutions for the busy librarian" within the library UX literature. ${ }^{127}$ In the current environment of austerity, more long-term, open-ended ethnographic research may appear "too risky" to "cash-strapped" library directors seeking the "quick payoffs" of "low investment high yield projects." 128 The concept of experience is consequently further diminished through the superficiality of the methods that are used to explore user interaction, leading Lanclos and Asher to advocate for the use of "more widespread and deeply practiced... ethnographic methods" that would instead allow for a "transformative moment...[in which] libraries can actually be thought about and experienced differently, not just rearranged." 129

\section{Conclusion: Toward a Critical Turn in Library UX}

As we were writing this paper, librarian Andrew Preater tweeted about the need for a critical turn within $\mathrm{UX}^{130}$ joining the handful of practitioners and researchers calling for a closer look at library UX methods and outcomes. This paper is our attempt to contribute to the creation of such a critical library UX practice. However, ours is but one possible approach; we note 
that there is still a great deal of work that needs to be done in this sphere.

Research that has explored design through an antiracist lens may provide a model for one key way in which critical library UX could be approached. ${ }^{131}$ As various commentators have pointed out, and particularly in the light of the Black Lives Matter demonstrations and protests of 2020, "from policy to programming to people, libraries, information organizations, and companies that build information systems are uniquely positioned to inflict structural violence on BIPOC." ${ }^{132}$ Built environments, both physical and virtual, cannot be seen as neutral. Instead, they produce both intentional and unintentional effects that "reflect and signal racism." ${ }^{133}$ Along these lines, designing against anti-Black racism in our built structures as well as in our policies, services, and collections must be seen as a key imperative for library UX researchers and practitioners as well as for the architects and planners with whom we work. The recognition that direct action such as sit-ins form a design tactic means that an antiracist UX lens must also honor a "legacy of protest as design and world-building,"134 an idea that rebodies our understanding of UX while further testing commitment to participatory and student-centered design tactics. At the same time, the Critical Design Lab advocates against projects that "capitalize upon or behave entrepreneurially toward our present crisis," warning that design-a-thons and grant-funded projects often work to depoliticize rather than to foster systemic change. ${ }^{135}$ In this sense, antiracist design pushes back against the quick fixes and the performative gestures that have come to characterize much Library UX work to center mutual aid and social support as well as care in the wider community.

Critical UX could also be approached through intersectional feminist or disability lenses, both of which aim to center people who "are normally marginalised by design." 136 Recognizing that design processes typically reproduce the matrix of domination, which includes white supremacy, heteropatriarchy, capitalism, and settler colonialism, a feminist design framework builds on Design Justice Network Principles to emphasize how we want design to work as well as how it currently functions. ${ }^{137}$ From a library UX perspective, these principles center an examination of the values that are embedded within choices of design beneficiaries as well as objects and systems. These ideas are picked up on in "crip technoscience," which is a form of politicized design activism that emerged from a recognition that technologies and infrastructures are often "designed and implemented without committing to disability as a difference that matters." 138 Positioning disabled people as active participants rather than consumers of or objects for design processes, crip technoscience also recognizes that problematic structures mean that many disabled people are already "tinkering with existing material arrangements." 139 For library UX, this framework calls for the need to acknowledge the "lived experiences and material design practices of disabled people"140 in design projects while further encouraging the problematization of access and accessibility, which is often seen to promote integration rather than politicized resistance. ${ }^{141}$ These approaches recenter history, context, materiality, and lived experience in the library rather than reaffirming neutrality, disembodiment, and uninterrogated whiteness.

Another approach that could be employed to extend critical understandings of UX is to re-examine LIS research to pay attention to what is missed when we rely too heavily on theoretical approaches developed from different disciplinary traditions. Suominen's 2007 exploration of userism, which critiques the privileged position that users are accorded in LIS, provides one example. ${ }^{142}$ Noting that a user orientation that excludes any other perspectives forms a problematic and individualistic ideology, Suominen points out that when the 
user is "the only intelligibly possible actor whose interests could legitimate the existence of a library," other considerations will remain "marginal."143 Along the same lines, LIS research that has explored how a focus on individuals rather than their broader social practices has led to the construction of "ignorant," 144 "needy,"145 and "worthy"146 users form another way in which library UX could be reimagined. This research, which underscores the ways in which user discourse risks positioning users as problematic or troublesome, mirrors recent work that explores deficit discourse in information literacy. ${ }^{147}$ An attention to LIS literature further raises a number of questions about our reliance on values and assumptions from outside our field, while acknowledging and returning full circle to the early LIS research that played such an important role in original conceptions of user experience work.

In this paper, we explored the origins and values of UX through a critical lens. Drawing on research from a variety of disciplines, we traced the historical antecedents of UX as well as its manifestations within academic libraries, drawing attention to various sites of tension between UX and library values. In so doing, our goal was to lay the groundwork for a library UX practice more closely aligned with the critical turn in LIS that acknowledges critical and feminist perspectives on practice, embodiment, and power.

\section{Notes}

1. Penny Andrews, "User Experience Beyond Ramps: The Invisible Problem and the Special Case," in User Experience in Libraries. Applying Ethnography and Human-Centred Design, eds. Andy Priestner and Matt Borg (Basingstoke, UK: Taylor \& Francis, 2016), 108-20, http://eprints.whiterose.ac.uk/102925/; Karine Larose and Simon Barron, "How White Is Your UX Practice? Inclusion and Diversity in Critical UX Research," in User Experience in Libraries: Yearbook 2017, ed. Andy Priestner (Scotts Valley, CA: CreateSpace Independent Publishing Platform, 2017), 23-33, http://eprints.rclis.org/32461/.

2. Andrews, "User Experience Beyond Ramps"; Larose and Barron, "How White Is Your UX Practice?"; Donna Lanclos and Andrew Asher, "'Ethnographish': The State of Ethnography in Libraries," Weave: Journal of Library User Experience 1, no. 5 (2016): n.p., https://doi.org/10.3998/weave.12535642.0001.503; Scott W.H. Young and Celina Brownotter, "Toward a More Just Library: Participatory Design with Native American Students," Weave: Journal of Library User Experience 1, no. 9 (2018): n.p., https://doi.org/http://dx.doi.org/10.3998/weave.12535642.0001.901; Danielle Cooper, "When Research Is Relational: Supporting the Changing Research Practices of Indigenous Studies Scholars," Copyright, Fair Use, Scholarly Communication, etc. 107 (2019): 1-36, https://digitalcommons.unl. edu/scholcom/107; Matthew Reidsma, Masked by Trust: Bias in Library Discovery (Sacramento, CA: Library Juice Press, 2019).

3. Michele R. Santamaria, "Concealing White Supremacy through Fantasies of the Library: Economies of Affect at Work," Library Trends 68, no. 3 (2020): 431, https://doi.org/10.1353/lib.2020.0000.

4. Effie Law et al., "Towards a Shared Definition of User Experience," in Proceedings of the Twenty-Sixth Annual CHI Conference Extended Abstracts on Human Factors in Computing Systems: CHI '08, Florence, Italy, April 2008, 2395-98, https://doi.org/10.1145/1358628.1358693.

5. Bonnie Urciuoli, "Skills and Selves in the New Workplace," American Ethnologist 35, no. 2 (2008): 211-28, https://doi.org/10.1111/j.1548-1425.2008.00031.x.

6. Don Norman and Jakob Nielsen, “The Definition of User Experience" (2007), https://www.nngroup.com/ articles/definition-user-experience/.

7. Law et al., "Towards a Shared Definition of User Experience," 2396.

8. Effie Law et al., “Understanding, Scoping and Defining USer eXperience: A Survey Approach,” in CHI '09: CHI Conference on Human Factors in Computing Systems, Boston, MA, 2009, 726, https://doi.org/10.1145/1518701.1518813.

9. International Organization for Standardization (ISO), Ergonomics of Human-System Interaction-Part 210: Human-centred Design for Interactive Systems. ISO 9241-210:2019, Geneva: ISO, published July 2019, https:// www.iso.org/standard/77520.html.

10. Shaheen Amirebrahimi, "The Rise of the User and the Fall of People: Ethnographic Cooptation and a New Language of Globalization," in Ethnographic Praxis in Industry Conference Proceedings 2016, 71-103, https:// doi.org/10.1111/1559-8918.2016.01077.

11. As a member of an interdisciplinary team of social scientists in the early 1990s, Norman was a co-author 
of "one of the first papers to use the phrase 'user experience."' Amirebrahimi, "The Rise of the User and the Fall of People," 81.

12. Amirebrahimi, "The Rise of the User and the Fall of People," 80.

13. Amirebrahimi, "The Rise of the User and the Fall of People," 81.

14. Amirebrahimi, "The Rise of the User and the Fall of People," 81.

15. Shaheen Amirebrahimi, "Moments of Disjuncture: The Value of Corporate Ethnography in the Research Industrial Complex," in Ethnographic Praxis in Industry Conference Proceedings 2015, 13-23, https://doi. org/10.1111/1559-8918.2015.01036.

16. Megan Sapnar Ankerson, Dot-Com Design: The Rise of a Usable, Social, Commercial Web (New York: New York University Press, 2018), 4.

17. Ankerson, Dot-Com Design, 23.

18. Ankerson, Dot-Com Design, 170, 5.

19. Ankerson, Dot-Com Design, 163.

20. Ankerson, Dot-Com Design, 165.

21. Ankerson, Dot-Com Design, 163.

22. Ankerson, Dot-Com Design, 13.

23. David Bawden, "Users, User Studies and Human Information Behaviour: A Three-Decade Perspective on Tom Wilson's ‘On User Studies and Information Needs,'” Journal of Documentation 62, no. 6 (2006): 671-79, https://doi.org/10.1108/00220410610714903.

24. Saul Herner, "The Library and Information User-Then and Now," Bulletin of the American Society for Information Science (March 1976): 33.

25. Lowell Martin, “User Studies and Library Planning,” Library Trends 24, no. 3 (1976): 483-96.

26. Ankerson, Dot-Com Design, 193.

27. Jonathan Grudin, From Tool to Partner: The Evolution of Human-Computer Interaction (San Rafael, CA: Morgan \& Claypool, 2017).

28. Robert Fox and Ameet Doshi, Library User Experience. SPEC Kit 322 (Washington, DC: Association of Research Libraries, July 2011), 11, https://doi.org/10.29242/spec.322.

29. Nancy Fried Foster and Susan Gibbons, Studying Students: The Undergraduate Research Project at the University of Rochester (Chicago, IL: Association of College \& Research Libraries, 2007).

30. Foster and Gibbons, Studying Students, v.

31. Valeda Dent Goodman, "Applying Ethnographic Research Methods in Library and

Information Settings," Libri 61, no. 1 (2011): 1-11, https://doi.org/10.1515/libr.2011.001; Bawden, “Users, User Studies and Human Information Behaviour;" Herner, "The Library and Information User-Then and Now"; Martin, "User Studies and Library Planning."

32. See also, for example, Maura Smale and Mariana Regalado, The Scholarly Habits of the Undergraduates at CUNY: Preliminary Results (2011), http://ushep.commons.gc.cuny.edu/files/2011/01/ushep-prelim-report1.pdf; Lynda Duke and Andrew Asher, College Libraries and Student Culture: What We Now Know (Chicago, IL: American Library Association, 2012); Henry Delcore, James Mullooly, and Michael Scroggins, The Library Study at Fresno State (Fresno, CA: Institute of Public Anthropology, California State University, Fresno, 2009).

33. Donald Beagle, The Information Commons Handbook (New York, NY: Neal Schuman Publishers, 2006); Scott Bennett, "The Information or the Learning Commons: Which Will We Have?" Journal of Academic Librarianship 34, no. 3 (2008): 183-85.

34. Foster and Gibbons, Studying Students, 74.

35. Andrew Asher and Susan Miller, So You Want to Do Anthropology in Your Library? Or A Practical Guide to Ethnographic Research in Academic Libraries, n.d., 2, www.erialproject.org/wp-content/uploads/2011/03/Toolkit-3.22.11.pdf.

36. Lanclos and Asher, "Ethnographish."

37. Donna Lanclos, "Embracing an Ethnographic Agenda: Context, Collaboration, and Complexity," in User Experience in Libraries: Applying Ethnography and Human-Centred Design, eds. Andy Priestner and Matt Borg (Basingstoke, UK: Taylor \& Francis, 2016), 24.

38. Cecily Walker, "A User Experience Primer," Feliciter 56, no. 5 (2010): 195; Elizabeth M. Downey and Stephen Abram, "Our User Experience: Puzzle Pieces Falling into Place-Workshop Report," Serials Librarian 55, no. 3 (2008): 461-68, https://doi.org/10.1080/03615260802059742.

39. Andy Priestner, “UXLibs: A New Breed of Conference," CILIP Update (2015).

40. Aaron Schmidt and Amanda Etches, Useful, Usable, Desirable: Applying User Experience Design to Your Library (Chicago, IL: ALA Editions, 2014), 2.

41. Priestner, "UXLibs: A New Breed of Conference." 
42. Aaron Schmidt and Amanda Etches, User Experience (UX) Design for Libraries (Chicago: American Library Association, 2012), 2.

43. Schmidt and Etches, Useful, Usable, Desirable, 3.

44. Lanclos and Asher, "Ethnographish."

45. User Experience in Libraries. Applying Ethnography and Human-Centred Design, eds. Andy Priestner and Matt Borg (Basingstoke, UK: Taylor \& Francis, 2016), 24.

46. Schmidt and Etches, User Experience (UX) Design for Libraries, 2.

47. Tamar Sadeh, "Time for a Change: New Approaches for a New Generation of Library Users," New Library World 108, no. 7/8 (2017): 307-16, https://doi.org/10.1108/03074800710763608.

48. Janet Chisman, Karen Diller, and Sharon Walbridge, "Usability Testing: A Case Study," College \& Research Libraries 60, no. 6 (1999): 552-69, https://doi.org/10.5860/crl.60.6.552.

49. Leslie Porter, "Library Applications of Business Usability Testing Strategies," Library Hi Tech 25, no. 1 (2007): 126-35, https://doi.org/10.1108/07378830710735902.

50. Tom Lehman and Terry Nikkel, Making Library Web Sites Usable: A LITA Guide (New York, NY: NealSchuman, 2008).

51. Elaina Norlin and CM! Winters, Usability Testing for Library Websites: A Hands-On Guide (Chicago, IL: American Library Association, 2002).

52. Carole George, User-Centred Library Websites: Usability Evaluation Methods (Oxford, UK: Chandos, 2008), 13.

53. Norlin and Winters, Usability Testing for Library Websites, 3; George, User-Centred Library Websites, 4.

54. Steven Bell and John Shank, Academic Librarianship by Design: A Blended Librarian's Guide to the Tools and Techniques (Chicago, IL: ALA Editions, 2007).

55. Ryne Leuzinger, Gina Kessler Lee, and Irene Korber, "Keeping Up with ...Design Thinking” (Chicago, IL: American Library Association, January 16, 2018), www.ala.org/acrl/publications/keeping_up_with/design.

56. IDEO, Design Thinking for Libraries: A Toolkit for Patron-Centered Design (Palo Alto, CA: IDEO, 2015); Schmidt and Etches, User Experience (UX) Design for Libraries; Schmidt and Etches, Useful, Usable, Desirable.

57. Steven Bell, “Delivering an Amazon-Like Experience," Designing Better Libraries (January 12, 2018), http:// dbl.lishost.org/blog/2018/01/12/delivering-an-amazon-like-experience/.

58. See James Woudhuysen, “The Craze for Design Thinking: Roots, A Critique, and Toward an Alternative," Design Principles and Practices: An International Journal 5, no. 6 (2011): 235-48, https://www.dora.dmu.ac.uk/ handle/2086/5561.

59. Cinthya Ippolitti, "Research as Design-Design as Research: Applying Design Thinking to Data Management Needs Assessment," in The 2016 Library Assessment Conference: Building Effective, Sustainable, Practical Assessment (Washington, DC: Association of Research Libraries, 2016); Linda Whang et al., "Understanding the Transfer Student Experience Using Design Thinking," Reference Services Review 45, no. 2 (2017): 298-313, https:// doi.org/10.1108/RSR-10-2016-0073.

60. Leuzinger, Kessler Lee, and Korber, "Keeping Up with ...Design Thinking”; Jonathan Eldredge, “EvidenceBased Librarianship: An Overview," Bulletin of the Medical Library Association 88, no. 4 (2000): 289-302; Ankerson, Dot-Com Design.

61. Michael Khoo, Lily Rozaklis, and Catherine Hall, "A Survey of the Use of Ethnographic Methods in the Study of Libraries and Library Users," Library E Information Science Research 34, no. 2 (2012): 82-91, https://doi. org/10.1016/j.lisr.2011.07.010.

62. Priestner, "UXLibs: A New Breed of Conference."

63. Buddy Pennington et al., "Strategies to Improve the User Experience," Serials Review 42, no. 1 (2016): 47-58, https://doi.org/10.1080/00987913.2016.1140614; Michelle Boisvenue-Fox et al., "Collection Development and User Experience Symposia," Weave: Journal of Library User Experience 1, no. 8 (2018): n.p., https://doi.org/10.3998/ weave.12535642.0001.804; Hannah McKelvey and Jacqueline L. Frank, "Improving Onboarding with Employee Experience Journey Mapping: A Fresh Take on a Traditional UX Technique," Weave: Journal of Library User Experience 1, no. 9 (2018): n.p., https://doi.org/10.3998/weave.12535642.0001.903.

64. Leo Appleton, "Qualitative Methods for Engaging Students in Performance Measurement," Information and Learning Science 119, no. 1 (2018): 64-76, https://doi.org/10.1108/ILS-09-2017-0093; Katie Burn, Matthew Cunningham, Liz Waller, Emma Walton, and Graham Walton, "Capturing The Student User Experience (UX) In York And Loughborough University Library Buildings", Performance Measurement and Metrics 17, No. 2 (2016):. 175-187, https://doi.org/10.1108/PMM-04-2016-0021.

65. Lanclos and Asher, "Ethnographish."

66. Andrews, "User Experience Beyond Ramps," 114.

67. Young and Brownotter, "Toward a More Just Library"; Cooper, "When Research Is Relational." 
68. Gary P. Radford, Marie L. Radford, and Jessica Lingel, "The Library as Heterotopia: Michel Foucault and the Experience of Library Space," Journal of Documentation 71, no. 4 (2015): 733-51, https://doi.org/10.1108/JD-012014-0006.

69. Santamaria, "Concealing White Supremacy through Fantasies of the Library," 431.

70. Ankerson, Dot-com Design.

71. Sanna Talja and Jenna Hartel, "Revisiting the User-centred Turn in Information Science Research: An Intellectual History Perspective," Information Research 12, no. 4 (2007): n.p., http://informationr.net/ir/12-4/colis04. html.

72. Talja and Hartel, "Revisiting the User-centred Turn in Information Science Research."

73. Talja and Hartel, "Revisiting the User-centred Turn in Information Science Research."

74. Kimmo Tuominen, "User-centered Discourse: An Analysis of the Subject Positions of the User and the Librarian," Library Quarterly 67, no. 4 (1997): 350-71.

75. Kris R. Cohen, "Who We Talk about When We Talk about Users," EPIC 2005 Ethnographic Praxis in Industry Conference, November 2005, 11, https://anthrosource.onlinelibrary.wiley.com/doi/pdf/10.1111/j.1559-8918.2005. tb00005.x.

76. Cohen, "Who We Talk about When We Talk about Users," 15.

77. Cohen, "Who We Talk about When We Talk about Users," 14.

78. Reidsma, Masked by Trust, 155.

79. Cohen, "Who We Talk about When We Talk about Users," 15.

80. Sasha Costanza-Chock, "Design Justice: Towards an Intersectional Feminist Framework for Design Theory and Practice," in Proceedings of the Design Research Society 2018, n.p., https://doi.org/10.21606/dma.2017.679.

81. Sara Henren, “The Tyranny of Chairs: Why We Need Better Design," The Guardian (August 25, 2020), https://www.theguardian.com/artanddesign/2020/aug/25/the-tyranny-of-chairs; Rachel Ivy Clarke, "From 'Library Science' to 'Library Design': Recasting the Narrative of Academic Librarianship," in ALA Annual Conference 2019, www.ala.org/acrl/sites/ala.org.acrl/files/content/conferences/confsandpreconfs/2019/FromLibraryScienceLibraryDesign.pdf.

82. Adrienne L. Massanari, “Designing for Imaginary Friends: Information Architecture, Personas and the Politics of User-Centered Design," New Media E Society 12, no. 3 (May 2010): 407, https://doi. org/10.1177/1461444809346722.

83. Alex Sundt and Elizabeth Davis, "User Personas as a Shared Lens for Library UX," Weave: Journal of Library User Experience 1, no. 6 (2017): n.p., https://doi.org/10.3998/weave.12535642.0001.601; Massanari, “Designing for Imaginary Friends."

84. Phil Turner and Susan Turner, "Is Stereotyping Inevitable When Designing with Personas?" Design Studies 32, no. 1 (2011): 34, https://doi.org/10.1016/j.destud.2010.06.002.

85. Joe Marquez and Annie Downey, "Service Design: An Introduction to a Holistic Assessment Methodology of Library Services," Weave: Journal of Library User Experience 1, no. 2 (2015): n.p., https://doi.org/10.3998/ weave.12535642.0001.201

86. Turner and Turner, “Is Stereotyping Inevitable When Designing with Personas?"; Sundt and Davis, “User Personas as a Shared Lens for Library UX"; Massanari, "Designing for Imaginary Friends."

87. Massanari, "Designing for Imaginary Friends," 409, 411. Platzer notes that "pain points," another UX tool, function in much the same way. David Platzer, "Regarding the Pain of Users: Towards a Genealogy of the 'Pain Point,"' in Ethnographic Praxis in Industry Conference Proceedings (October 2018), 301-15, https://doi.org/10.1111/15598918.2018.01209.

88. Dan Saffer, "Persona Non Grata," Adaptive Path (August 17, 2005), quoted in Massanari, “Designing for Imaginary Friends," 409.

89. Lanclos and Asher, "Ethnographish."

90. Lanclos and Asher, "Ethnographish."

91. Massanari, “Designing for Imaginary Friends," 409.

92. Carol Conrad, "Cognitive Economy in Semantic Memory," Journal of Experimental Psychology 92, no. 2 (1972): 149-54, https://doi.org/10.1037/h0032072.

93. Turner and Turner, "Is Stereotyping Inevitable When Designing with Personas?" 39.

94. Turner and Turner, "Is Stereotyping Inevitable When Designing with Personas?" 39.

95. David James Hudson, "The Whiteness of Practicality," in Topographies of Whiteness: Mapping Whiteness in Library and Information Studies, ed. Gina Schlesselman-Tarango (Sacramento, CA: Library Juice Press, 2017), 212.

96. Angela Groth-Seary and Ben Watson, "A Degree of Difference? Information Experiences of Students with Print Disabilities," in User Experience in Libraries, ed. Andrew Priestner (Goxhill, Lincolnshire, UK: UX In Libraries), 148-54; Andrews, “User Experience Beyond Ramps," 114; Larose and Barron, "How White Is Your 
UX Practice?"; Catherine Pontoriero and Gina Zippo-Mazur, "Evaluating the User Experience of Patrons with Disabilities at a Community College Library," Library Trends 67, no. 3 (2019): 497-515, https://doi.org/10.1353/ lib.2019.0009/.

97. Marquez and Downey, "Service Design."

98. Michael A. Arthur and Erin Gallagher, "Being Earnest with Collections-User-Centered Collection Development: Using Library Service Design Tools to Evaluate Development: Using Library Service Design Tools to Evaluate Open Access Funding Opportunities," Against the Grain (2018/19): 64-65, https://docs.lib.purdue.edu/ atg/vol30/iss6/34/.

99. Marquez and Downey, "Service Design."

100. The RUSA Guidelines similarly establish "a reference encounter as occurring free of context, circumstance, or qualification" and measure "the success of the interaction in the (female) librarian's successful performance of emotional labor." Cecilia Emmelhainz, Erin Pappas, and Maura Seale, "Behavioral Expectations for the Mommy Librarian: The Successful Reference Transaction as Emotional Labor," in The Feminist Reference Desk: Concepts, Critiques, and Conversations, ed. Maria Accardi (Sacramento, CA: Library Juice Press, 2017), 31, https://escholarship.org/uc/item/2mq851m0.

101. Marquez and Downey, "Service Design."

102. Gailey describes hyper(in)visibility as "the seemingly paradoxical social position of being paid exceptional attention while simultaneously being erased" that characterizes the experience of fat women. Jeannine A. Gailey, The Hyper(in)visible Fat Woman: Weight and Gender Discourse in Contemporary Society (New York, NY: Palgrave Macmillan, 2014).

103. Steven Bell, “UXF: Where's the Friction at Your Library,” Designing Better Libraries (March 22, 2017), https:// sites.temple.edu/stevenb/2017/03/22/uxf-wheres-the-friction-at-your-library/; Steven J. Bell, "Staying True to the Core: Designing the Future Academic Library Experience," portal: Libraries and the Academy 14, no. 3 (2014): 369-82, https://doi.org/10.1353/pla.2014.0021; Steven Bell, "Higher Education Promotes the Student Experience I From the Bell Tower," Library Journal (May 17, 2018), http://www.libraryjournal.com/?detailStory=higher-educationpromotes-student-experience-bell-tower.

104. See, for example, Santamaria, "Concealing White Supremacy through Fantasies of the Library"; Pushing the Margins: Women of Color and Intersectionality in LIS, eds. Rose Chou and Annie Pho (Sacramento, CA: Library Juice Press, 2018); Nicola Andrews, "Reflections on Resistance, Decolonization, and the Historical Trauma of Libraries and Academia," in The Politics of Theory and the Practice of Critical Librarianship, eds. Karen P. Nicholson and Maura Seale (Sacramento, CA: Library Juice Press), 181-94; Jessie Loyer, "Indigenous Information Literacy: nêhiyaw Kinship Enabling Self-care in Research," in The Politics of Theory and the Practice of Critical Librarianship, eds. Karen P. Nicholson and Maura Seale (Sacramento, CA: Library Juice Press), 145-56; Jessica Schomberg, "Disability at Work: Libraries, Built to Exclude," in The Politics of Theory and the Practice of Critical Librarianship, eds. Karen P. Nicholson and Maura Seale (Sacramento, CA: Library Juice Press), 115-27; Schlesselman-Tarango, Topographies of Whiteness; Andrews, "User Experience Beyond Ramps."

105. Easing "friction" by effacing the "messiness" of human interactions is key to platform capitalism; surveillance capitalism further "ease[s] 'friction' through dehumanization on the basis of race, class, and gender identity." Chris Gilliard, "Friction-free Racism: Surveillance Capitalism Turns a Profit by Making People More Comfortable with Discrimination," Real Life: Action at a Distance (October 15, 2018): n.p., https://reallifemag.com/ friction-free-racism/.

106. Suzanne L. Thomas and Tony Salvador, "Skillful Strategy, Artful Navigation \& Necessary Wrangling," Ethnographic Praxis in Industry Conference Proceedings (2006), 109-24, https://doi.org/10.1111/j.1559-8918.2006. tb00040.x. According to Lundberg, "Work Like a Patron Day" started in 2008 and is now part of National Library Week in the United States. Sabina Lundberg, "Change or Die: A Study on the Phenomenon of Library UX at Two Academic Libraries in Sweden" (master's thesis, Uppsala University, 2017), http://uu.diva-portal.org/smash/get/ diva2:1208741/FULLTEXT01.pdf.

107. Cohen, "Who We Talk about When We Talk about Users," 20.

108. Duna Sabri, "What's Wrong with 'the Student Experience'?" Discourse: Studies in the Cultural Politics of Education 32, no. 5 (2011): 657-67, https://doi.org/10.1080/01596306.2011.620750.

109. John Dewey, “Experience and Education," The Educational Forum 50, no. 3 (1986): 241-52.

110. Law et al., "Understanding, Scoping and Defining User eXperience."

111. Sabri, "What's Wrong with 'the Student Experience'?" 664.

112. Sabri, "What's Wrong with 'the Student Experience'?" 665.

113. Sabri, "What's Wrong with 'the Student Experience'?" 665.

114. Sarah Sharma, In the Meantime: Temporality and Cultural Politics (Raleigh-Durham, NC: Duke University Press, 2014), 13. 
115. Amirebrahimi, "Moments of Disjuncture," 17.

116. Amirebrahimi, "Moments of Disjuncture," 14.

117. Amirebrahimi, "Moments of Disjuncture," 14.

118. Beverly P. Lynch, “Libraries as Bureaucracies," Library Trends 27 (1979): 259-67.

119. Brian Quinn, "The McDonaldization of Academic Libraries?" College \& Research Libraries 61, no. 3 (2000): 248-61, https://doi.org/10.5860/crl.76.3.339; Karen P. Nicholson, "The McDonaldization of Academic Libraries and the Values of Transformational Change," College E Research Libraries 76, no. 3 (2015): 328-38, https://doi.org/10.5860/ crl.76.3.328.

120. Catherine Closet-Crane, "A Critical Analysis of the Discourse on Academic Libraries as Learning Places," Advances in Library Administration and Organization 30 (2011): 1-50, https://doi.org/10.1108/S07320671(2011)0000030004; Karen P. Nicholson, Nicole Pagowsky, and Maura Seale, “Just-in-Time or Just-in-Case? Time, Learning Analytics, and the Academic Library," Library Trends 68, no. 1 (2019): 54-75, https://doi.org/10.1353/ lib.2019.0030.

121. Julia Glassman, "The Innovation Fetish and Slow Librarianship: What Librarians Can Learn from the Juicero," In the Library with the Lead Pipe (October 18, 2017), www.inthelibrarywiththeleadpipe.org/2017/theinnovation-fetish-and-slow-librarianship-what-librarians-can-learn-from-the-juicero/.

122. Lundberg, "Change or Die."

123. Lundberg, "Change or Die," 11.

124. Craig M. MacDonald, “'It Takes a Village': On UX Librarianship and Building UX Capacity in Libraries," Journal of Library Administration 57, no. 2 (February 17, 2017): 194-214, https://doi.org/10.1080/01930826.2016.12329 42.

125. MacDonald, “It Takes a Village," 199.

126. Lundberg, "Change or Die."

127. Emily Mitchell and Brandon West, "DIY Usability: Low-Barrier Solutions for the Busy Librarian," Weave: Journal of Library User Experience 1, no. 5 (2016), https://doi.org/10.3998/weave.12535642.0001.504; Craig M. MacDonald, “User Experience Librarians: User Advocates, User Researchers, Usability Evaluators, or All of the Above?" Proceedings of the Association for Information Science and Technology 52, no. 1 (2015): 1-10, https://doi. org/10.1002/pra2.2015.145052010055; Pete Coco and Matthew Reidsma, "The UX Moment: A Weave Digital Panel, Part One," Weave: Journal of Library User Experience 1, no. 2 (2015), https://doi.org/10.3998/weave.12535642.0001.203.

128. Lanclos and Asher, "Ethnographish."

129. Lanclos and Asher, "Ethnographish."

130. Andrew Preater (@preater), “Library UX IMO (Hot Take Alert) Hasn't Been Pushed around a ‘Critical Turn,"' Twitter (June 20, 2019), https://twitter.com/preater/status/1141766419564179456.

131. See Sasha Costanza-Chock, Design Justice: Community-Led Practices to Build the Worlds We Need (Cambridge, MA: MIT Press, 2020), https://design-justice.pubpub.org/.

132. Amelia N. Gibson et al., "Struggling to Breathe: COVID-19, Protest, and the LIS Response," https://cdr. lib.unc.edu/concern/parent/v118rk62f/file_sets/wd3762683.

133. "Critical Design Lab Statement on Design Commitments to Abolishing White Supremacy," Mapping Access: Anti-racist Critical Design (June 6, 2020), https://www.mapping-access.com/blog-1/2020/6/2/anti-racistcritical-deisgn.

134. "Critical Design Lab Statement on Design Commitments to Abolishing White Supremacy."

135. "Critical Design Lab Statement on Design Commitments to Abolishing White Supremacy."

136. Costanza-Chock, "Design Justice: Towards an Intersectional Feminist Framework for Design Theory and Practice."

137. Costanza-Chock, "Design Justice: Towards an Intersectional Feminist Framework for Design Theory and Practice."

138. Amy Hamraie and Kelly Fritsch, "Crip Technoscience Manifesto," Catalyst: Feminism, Theory, Technoscience 5, no. 1 (2019): 2, https://catalystjournal.org/index.php/catalyst/article/view/29607/24771.

139. Hamraie and Fritsch, "Crip Technoscience Manifesto," 4.

140. Hamraie and Fritsch, "Crip Technoscience Manifesto," 7.

141. Hamraie and Fritsch, "Crip Technoscience Manifesto," 10; Costanza-Chock, Design Justice: CommunityLed Practices to Build the Worlds We Need.

142. Vesa Suominen, "The Problem of 'Userism,' and How to Overcome it in Library Theory," Information Research 12, no. 4 (2007), http://informationr.net/ir/12-4/colis33.html.

143. Suominen, "The Problem of 'Userism,' and How to Overcome It in Library Theory."

144. Bernd Frohmann, "Cognitive Paradigms and User Needs," in Cognitive Paradigms in Knowledge Organization: Second International Isko Conference 1992, eds. A. Neelameghan et al. (Madras, India: Sarda Ranganathan 
Endowment for Library Science: 1992), 35-50.

145. Michael Olsson, "Beyond 'Needy' Individuals: Conceptualizing Information Behavior," Proceedings of the American Society for Information Science and Technology 42, no. 1 (2005), https://asistdl-onlinelibrary-wiley-com/ doi/pdfdirect/10.1002/meet.1450420161.

146. Pamela J. McKenzie, "How Do You Solve a Problem like the Whole User? The Construction of Worthy and Problematic Users in Online Discussions of the Public Library," Journal of the Australian Library and Information Association 68, no. 4 (2019): 371-96, https://doi.org/10.1080/24750158.2019.1670775.

147. Chelsea Heinbach, Brittany Paloma Fiedler, Rosan Mitola, and Emily Pattni, "Dismantling deficit thinking: A strengths-based inquiry into the experiences of transfer students in and out of academic libraries," In the Library with the Lead Pipe (2019): 498-510, http://www.inthelibrarywiththeleadpipe.org/2019/dismantling-deficitthinking/; Alison Hicks and Annemaree Lloyd, "Deconstructing information literacy discourse: Peeling back the layers in higher education," Journal of Librarianship and Information Science 53, no. 4 (2021): 559-571. 